\title{
Pengaruh Kompensasi Terhadap Kinerja Karyawan PT. Anugrah Tractor Machinery Sumatera
}

\author{
Benny Usman \\ Manajemen, Fakultas Ekonomi Universitas PGRI Palembang, \\ email: benny usman@univpgri-palembang.ac.id
}

\begin{abstract}
ABSTRAK
Tujuan dari penelitian ini berdasarkan perumusan masalah yang ada adalah untuk mengetahui pengaruh kompensasi terhadap kinerja karyawan PT Anugrah Tractor Machinery Sumatera. Metode pengumpulan data menggunakan kuisioner, wawancara (interview), dan dokumentasi. Teknik analisis data yang digunakan adalah analisis kuantitatif. Hasil analisis dalam penelitian ini bahwa kompensasi berpengaruh positif dan signifikan terhadap kinerja. Hal ini ditunjukkan dengan dari hasil perhitungan diperoleh $\mathrm{R}$ Square sebesar 0,497 yang dapat diartikan bahwa besarnya pengaruh variabel bebas terhadap variabel terikat dalam penelitian ini sebesar $49,7 \%$ dan yang lainnya dipengaruhi oleh variabel lain diluar variabel penelitian, sehingga adanya peningkatan pemberian kompensasi akan meningkatkan kinerja karyawan. Pernyataan di atas diperkuat oleh hasi uji-t, oleh karena nilai $t$ hitung $>t$ tabel $(6,888>2,011)$ dan nilai signifikansinya adalah sebesar 0,000 lebih kecil daripada taraf signifikansi (a) 0,05 , maka Ho ditolak, artinya bahwa ada pengaruh secara signifikan antara kompensasi dengan kinerja. Jadi dalam kasus ini dapat disimpulkan bahwa kompensasi berpengaruh terhadap kinerja pada PT Anugrah Tractor Machinery Sumatera.
\end{abstract}

Kata Kunci : Kompensasi, Kinerja.

\section{A. Latar Belakang}

PT Anugrah Tractor Machinery Sumatera adalah salah satu badan usaha yang bergerak pada bidang kontraktor untuk batu bara. Perusahan ini berusaha agar tetap hidup dan berkembang sehingga dapat mencapai tujuan atau keuntungan serta dapat melayani dan memenuhi keinginan dan kebutuhan masyarakat dengan sebaik mungkin. Dalam melaksanakan aktivitasnya, perusahaan menginginkan agar semua karyawan dapat melakukan pekerjaan atau tugas mereka dengan baik sehingga dapat mencapai prestasi kerja yang diharapkan. Tetapi disisi lain masih banyak faktor-faktor yang mempengaruhi kinerja karyawan yang belum semua terpenuhi hingga mencapai tingkat kepuasan salah satunya adalah masalah kompensasi yang diterima karyawan.
Suatu perusahaan akan meningkat kinerjanya bila adanya kerjasama dan hubungan yang baik antara pimpinan dan karyawannya. Sebaiknya karyawan diperlakukan seperti partner usaha dan bukan sebagai buruh semata. Hubungan kerja yang saling menguntungkan antara perusahaan dan karyawan sangat diperlukan dalam rangka mendorong semangat kerja karyawan.

Kedudukan sumber daya manusia di dalam perusahaan sangat penting. Oleh karena itu dibutuhkan manajemen sumber daya manusia agar pengelolaan sumber daya manusia dapat berjalan sesuai dengan apa yang diharapkan perusahaan. Dalam bukunya Manajemen Sumber Daya Manusia, Rahmawati (2007:3) mengungkapkan "Manajemen sumber daya manusia merupakan perencanaan, pengorganisasian, 
$\begin{array}{lr}\text { pengarahan dan } & \begin{array}{c}\text { pengawasan } \\ \text { kegiatan-kegiatan }\end{array} \\ \text { pengemadaaan, } \\ \text { pengembangan, }\end{array} \begin{array}{r}\text { pemberian } \\ \text { pengupanan, } \\ \text { pengintegrasian, } \\ \text { daya manusia agar tercpai berbagai } \\ \text { tujuan individu, organisasi dan } \\ \text { masyarakat". }\end{array}$

Sadar akan pentingnya sumber daya manusia bagi kelangsungan hidup dan kemajuan suatu perusahaan, maka suatu perusahaan hendaknya memberikan perhatian khusus, dan sudah sewajarnya pemilik perusahaan memandang sumber daya manusia lebih dari sekedar aset utama perusahaan dan menjadikan mitra dalam berusaha. Perusahaan harus dapat bersikap adil atas apa yang telah diberikan oleh sumber daya manusia kepada perusahaan, karena setiap karyawan berhak mendapatkan penghargaan dan perlakuan yang adil dari pimpinannya sebagai timbal balik atas jasa yang diberikannya, sehingga dapat mendorong para karyawan untuk lebih termotivasi dalam menjalankan kewajibannya sebagai seorang pekerja

Tidak adanya hubungan baik antara perusahaan dan karyawan sering terjadi tidak hanya di negara berkembang tetapi di negara maju sekalipun persoalan ini juga sering terjadi. Salah satu penyebabnya adalah tidak adanya kesepahaman terhadap sistem upah seperti yang sering terjadi di Indonesia pada khususnya. Hal ini tentu saja akan mengakibatkan ketidakpuasan karyawan terhadap perusahaan.

Dalam manajemen sumber daya manusia, kinerja karyawan merupakan salah satu hal yang penting dalam mewujudkan tujuan suatu perusahaan atau organisasi. Kinerja juga berarti prestasi kerja, pelaksanaan kerja, pencapaian kerja atau hasil kerja. Faktor penting yang mempengaruhi prestasi kerja atau kinerja adalah kepuasan kerja. Kepuasan kerja menurut Martoyo (2011:50) adalah keadaan emosional atau sikap dengan mana para karyawan memandang pekerjaan mereka. Kepuasan kerja mencerminkan perasaan seseorang terhadap pekerjaan dan segala sesuatu di lingkungan kerjanya.

Ketidakpuasan para karyawan dapat menimbulkan hal-hal yang tidak diinginkan yang dapat merugikan perusahaan yang bersangkutan. Misalnya ; aksi mogok kerja, ketidakhadiran karyawan meningkat, turunnya kinerja karyawan hingga sampai pada pengerusakan aset-aset perusahaan. Dalam kondisi seperti ini peran pimpinan dibutuhkan untuk mengerti apa yang menjadi keinginankeinginan kayawan sehingga dapat membuat karyawan puas dan meningkatkan kinerjanya.

\begin{tabular}{llr}
\multicolumn{1}{c}{ Menjadi } & \multicolumn{1}{c}{ kewajiban } & setiap \\
pimpinan & perusahaan & untuk \\
menciptakan & kepuasan kerja bagi
\end{tabular} karyawannya, karena kepuasan kerja merupakan faktor yang diyakini dapat mendorong dan mempengaruhi semangat kerja karyawan. Kepuasan kerja karyawan dapat tercapai salah satunya melalui pemberian kompensasi yang sesuai atas prestasi kerja yang telah diberikan dengan kata lain karyawan memberikan prestasi kerja yang baik untuk kemajuan perusahaan, sedangkan perusahaan memberikan kompensasi yang sesuai atas prestasi kerja yang telah diberikan karyawan terhadap perusahaan.

Samsuddin (2009:187-188) mengemukakan bahwa "Pemberian kompensasi dapat meningkatkan prestasi kerja dan motivasi karyawan. Oleh karena itu, perhatian organisasi atau perusahaan terhadap pengaturan secara rasional dan adil sangat diperlukan. Bila karyawan memandang pemberian kompensasi tidak memadai, presatsi kerja/kinerja, motivasi maupun 
kepuasan kerja mereka cenderung akan menurun".

Selama ini perusahaan telah memberikan kompensasi kepada karyawan baik kompensasi finansial (gaji, tunjangan, upah lembur, bonus, insentif dan lain-lain) dan non finansial (jabatan/jenjang karier). Akan tetapi dari hasil wawancara yang dilakukan penulis masih ada beberapa kekurangan dari pemberian kompensasi yang mengakibatkan kinerja karyawan menurun seperti kenaikan gaji dan tunjangan sering tidak memperhitungkan kondisi ekonomi secara global, tunjangan kesehatan/asuransi kesehatan yang kurang memadai, kondisi lingkungan perusahaan yang kurang kondusif (bising, kotor, fasilitas umum yang kurang memadai dan lain-lain), adanya kerancuan pada deskripsi kerja dan kekurangakuratan dalam evaluasi kerja yang dilakukan sehingga menjadi pememicu bertambah lemahnya kinerja karyawan.

\section{B. Rumusan Masalah}

Rumusan masalah dalam penelitian ini yaitu adakah pengaruh kompensasi terhadap kinerja karyawan pada PT Anugrah Tractor Machinery Sumatera.

\section{Metode Penelitian}

Berdasarkan tujuan berhubungan dengan judul yang dikemukakan, maka jenis penelitian yang digunakan adalah jenis penelitian explanatory (penelitian penjelasan) Menurut Nawawi (2006:5), "penelitian explanatory adalah untuk menjelaskan hubungan kausal antara variable-variabel melalui pengujian hipotesa". Penelitian ini menggunakan jenis penelitian explanatory karena peneliti ingin menjelaskan hubungan kausal yang terjadi antara variabelvariabel. Dalam pelaksanaanya penelitian explanatory menggunakan metode penelitian survai, dimana informasi dikumpulkan dari responden dengan menggunakan kuesioner. Menurut Nawawi (2006:3) "penelitian survai adalah penelitian yang mengambil sampel dari satu populasi dan menggunakan kuosioner sebagai alat pengumpulan data yang pokok".

\section{Populasi dan Sampel}

1) Populasi

Sugiyono

(2012:80-81)

mengemukakan bahwa "Populasi adalah wilayah generalisasi yang terdiri atas obyek/subyek yang mempunyai kualitas dan karakteristik tertentu yang ditetapkan oleh peneliti untuk dipelajari dan kemudian ditarik kesimpulannya, sedangkan sampel adalah bagian dari jumlah dan karakteristik yang dimiliki oleh populasi tersebut".

Populasi dalam penelitian ini adalah seluruh pegawai pada PT Anugrah Tractor Machinery Sumatera dengan jumlah pegawai sebanyak 50 orang.

2) Sampel

Sampel adalah bagian dari sejumlah karakteristik yang dimiliki populasi tersebut (Sugiyono, 2012:116). Dalam penelitian ini semua anggota populasi dijadikan responden. Sehingga penelitian ini merupakan penelitian populasi. Lebih lanjut Arikunto (2006:108), mengemukakan bahwa "suatu penelitian dikatakan penelitin populasi apabila seseorang ingin meneliti semua elemen yang ada di dalam wilayah penelitian, maka studi atau penelitiannya juga disebut studi populasi atau sensus. Dalam penelitian ini seluruh pegawai PT Anugrah Tractor Machinery Sumatera akan dijadikan sampel yaitu berjumlah 50 orang. 


\section{E. Teknik Pengumpulan Data}

Dalam usaha pengumpulan data serta keterangan penelitian mengunakan teknik pengumpulan data sebagai berikut:

1) Pengumpulan Data Primer

Pengumpulan data primer dalam penelitian ini dilakukan dengan menggunakan teknik sebagai berikut :

a. Kuesioner

Kuisioner merupakan alat untuk mengumpulkan data daftar pertanyaan tertulis yang disusun secara sistematis, pertanyaanpertanyaan yang terdapat dalam kuesioner, atau daftar pertanyaan tersebut cukup terperinci dan lengkap (Sugiyono, 2012:203).

b. Wawancara

Wawancara adalah proses memperoleh keterangan untuk tujuan penelitian dengan cara tanya jawab, sambil bertatap muka antara si penanya atau pewancara dengan si penjawab atau responden dengan menggunakan alat yang dinamakan interview guide (panduan wawancara). (Sugiyono, 2012:193).

2) Pengumpulan Data Sekunder

Pengumpulan data sekunder menggunakan teknik dokumentasi yaitu "teknik pengumpulan data yang tidak langsung ditujukan pada subyek penelitian, namun melalui dokumen. dokumen yang di gunakan dapat berupa buku harian atau catatan, laporan, dan dokumen lainnya" (Sugiyono, 2012:87).

\section{F. Teknik Analisis Data}

Sebelum data dianalisis, terlebih dahulu dilakukan pengolahan data. Setelah data tekumpul melalui kuesioner maka langkah selanjutnya adalah melakukan tabulasi, yaitu memberikan nilai (scoring) sesuai dengan sistem menggunakan skala pengukuran. Skala pengukuran merupakan kesepakatan yang digunakan sebagai acuan untuk menentukan panjang pendeknya interval yang ada dalam alat ukur, alat ukur tersebut digunakan dalam pengukuran akan menghasilkan data kuantitatif (Sugiyono, 2012:92).

Dalam penelitian ini, skala pengukuran yang digunakan adalah skala likert. Menurut Sugiyono (2012:135) skala likert digunakan untuk mengukur sikap, pendapat, dan persepsi seseorang atau sekelompok orang. Jawaban setiap item instrumen yang menggunakan skala likert mempunyai gradasi dari sangat positif sampai sangat negatif, yang dapat berupa kata-kata

\section{G. Hasil dan Pembahasan 1) Analisis Deskripsi Variabel}

Analisis deskripsi ini merupakan analisa terhadap variabel kompensasi dan kinerja. Analisa dilakukan berdasarkan jawaban dari responden terhadap masing-masing pertanyaan di setiap variabel.

Jawaban kuesioner dari responden akan akan dielompokkan berdasarkan masing-masing kriteria pada skala likert (skala 1-5). Kemudian jumlah responden dikelompokkan didalam setiap kriteria lalu dikalikan dengan bobotnya, dan hasil perkalian didalam setiap kriteria dijumlahkan kemudian dibagi dengan jumlah respondennya, sehingga diperoleh suatu nilai skor rataan yang berada pada skala $1 \mathrm{~s} / \mathrm{d} 5$ (Sugiyono, 2006:203). Cara menghitung Skor rataan adalah sebagai berikut:

$$
x=\frac{\sum f i . w i}{\sum f i}
$$

Keterangan

$x=$ skor rataan

$f i=$ frekuensi pada kategori ke- $i$ 
$w i=$ bobot untuk kategori ke-i

Hasil dari nilai skor rataan kemudian ditentukan rentang skala (1-5), yaitu sebagai berikut:

$$
R s=\frac{(m-1)}{m}
$$

Keterangan

$R s=$ rentang skala

$m=$ nilai maksimum alternatif jawaban
Berdasarkan rumus di atas maka rentang skala dalam penelitian ini adalah:

$$
R s=\frac{(5-1)}{5}=0.8
$$

Dengan demikian rentang skala jawaban responden dapat dikelompokkan sebagai berikut :

Tabel 1

Rentang Skala Item Jawaban Kuesioner

\begin{tabular}{|c|c|}
\hline Rentang Skala & Persepsi \\
\hline $1.00-1.80$ & Sangat rendah/Buruk \\
\hline $1.81-2.60$ & Rendah/Buruk \\
\hline $2.61-3.40$ & Sedang/Cukup \\
\hline $3.41-4.20$ & Baik/Tinggi \\
\hline $4.21-5.00$ & Sangat Baik/Sangat Tinggi \\
\hline \multicolumn{2}{|c|}{ Sumber : (Sugiono, 2012-203) } \\
\hline
\end{tabular}

\section{2) Uji Instrumen}

Uji instrumen dilakukan terhadap indikator dari masingmasing variabel agar dapat diketahui tingkat kevalidan dan keandalan indikator sebagaialat ukur variabel. Uji instrumen terdiri dari uji validitas dan reliabilitas.

\section{3) Uji Validitas}

Uji validitas dilakukan untuk mengukur sah atau tidaknya indikator atau kuesioner dari masingmasing variabel. Uji ini dapat mengungkapkan sejauh mana ketepatan alat pengukur mengungkapkan konsep kejadian yang diukur. Pengujian dilakukan dengan membandingkan $r$ hitung dan $r$ tabel. Nilai $r$ hitung merupakan hasil korelasi jawaban responden pada masing-masing pertanyaan di setiap variabel yang dianalisiss dengan program SPSS dan outputnya bernama corrected item correlation,. Sedangkan untuk mendapatkan $r$ tabel dilakukan dengan tabel $r$ product moment, yaitu menentukan $\alpha=0,05$ kemudian sampel
$=50$ sehingga didapat nilai $r$ tabel dua sisi sebesar 0,279. Tingkat kevalidan indikator atau kuesioner dapat ditentukan, apabila $r$ hitung $>r$ tabel $=$ Valid dan $r$ hitung $<r$ tabel = Tidak Valid. berikut adalah langkah-langkah dalam menguji validitas:

- Menentukan nilai $r$ tabel.

Dari tabel $r$, untuk df $=\mathrm{n}-2=50-$ $2=48, n=$ jumlah responden, dengan tingkat signifikan 5\%, maka terdapat angka $r$ tabel $=0,279$.

- Mencari nilai $r$ hitung

Dengan menggunakan bantuan software SPSS ver. 18 Nilai $r$ hitung untuk tiap item variabel $\mathrm{n}$ bisa dilihat pada tabel Item-Total Statistics kolom Corrected Item Total Correlation (Analyze - Scale Realibilit Analysis).

- Mengambil keputusan

Jika $r$ hitung positif, serta $r$ hitung $>$ $r$ tabel maka valid

Jika $r$ hitung tidak positif, serta $r$ hitung $<r$ tabel maka tidak valid Hasil uji validitas selengkapnya dapat dilihat pada tabel berikut: 
Tabel 2

Hasil Uji Validasi

\begin{tabular}{|c|c|c|c|c|}
\hline Variabel & Indikator & $r_{\text {hitung }}$ & $\mathbf{r}_{\text {tabel }}$ & Keterangan \\
\hline \multirow{12}{*}{ Kompensasi } & X.Item1 & 0.718 & \multirow{12}{*}{0,279} & \multirow{12}{*}{ Valid } \\
\hline & X.Item2 & 0.465 & & \\
\hline & X.Item3 & 0.583 & & \\
\hline & X.Item4 & 0.771 & & \\
\hline & X.Item5 & 0.514 & & \\
\hline & X.Item6 & 0.570 & & \\
\hline & X.Item7 & 0.440 & & \\
\hline & X.Item8 & 0.563 & & \\
\hline & X.Item9 & 0.575 & & \\
\hline & X.Item10 & 0.504 & & \\
\hline & X.Item11 & 0.458 & & \\
\hline & X.Item12 & 0.341 & & \\
\hline \multirow{12}{*}{ Kinerja } & Y.Item1 & 0.545 & \multirow{12}{*}{0,279} & \multirow{12}{*}{ Valid } \\
\hline & Y.Item2 & 0.536 & & \\
\hline & Y.Item3 & 0.404 & & \\
\hline & Y.Item4 & 0.551 & & \\
\hline & Y.Item5 & 0.495 & & \\
\hline & Y.Item6 & 0.403 & & \\
\hline & Y.Item7 & 0.299 & & \\
\hline & Y.Item8 & 0.569 & & \\
\hline & Y.Item9 & 0.280 & & \\
\hline & Y.Item10 & 0.479 & & \\
\hline & Y.Item11 & 0.415 & & \\
\hline & Y.Item12 & 0.483 & & \\
\hline
\end{tabular}

Sumber : Hasil Pengolahan Data Primer, 2018

Tabel 2 menunjukkan bahwa semua indikator yang digunakan untuk mengukur variabel kompensasi dan kinerja pegawai yang digunakan dalam penelitian ini mempunyai koefisien korelasi terkoreksi yang lebih besar dari $r$ table $=0,279$ (nilai $r$ tabel untuk subyek uji sebanyak 50). Hal ini berarti bahwa semua indikator tersebut adalah valid sebagai alat ukur variabel.

\section{4) Uji Reliabilitas}

Uji reliabilitas digunakan untuk mengetahui apakah indikator atau kuesioner yang digunakan dapat dipercaya atau handal sebagai alat ukur variabel. Reliabilitas suatu indikator atau kuesioner dapat dilihat dari nilai cronbach's alpha ( $\alpha$ ), yaitu apabila nilai cronbach's alpha ( $\alpha$ ) lebih besar (>) 0,60 maka indikator atau kuesioner adalah reliabel, sedangkan apabila nilai cronbach's alpha( $\alpha)$ lebih kecil (<) 0,60 maka indikator atau kuesioner tidak reliabel. Hasil pengolahandengan SPSS, diperoleh hasil sebagai berikut : 
Tabel 3

Hasil Uji Reliabilitas

\begin{tabular}{|c|c|c|c|}
\hline Variabel & cronbach's alpha & $\begin{array}{c}\text { Standar } \\
\text { Reliabilitas }\end{array}$ & Keterngan \\
\hline Kompensasi & 0,862 & 0,60 & Reliabel \\
\hline Kinerja & 0,809 & 0,60 & Reliabel \\
\hline
\end{tabular}

Sumber : Hasil Pengolahan Data Primer, 2018

Nilai cronbach's alpha semua variabel lebih besar dari 0,60, sehingga dapat disimpulkan indikator atau kuesioner yang digunakan variabel kompensasi dan kinerja, semua dinyatakan handal atau dapat dipercaya sebagai alat ukur variabel.

\section{5) Uji Asumsi Klasik}

Sebelum pengujian regresi dilakukan, terlebih dahulu dilakukan uji asumsi klasik. Uji asumsi klasik meliputi uji nomalitas, uji heteroskedastisitas, uji multikolinearitas, dan uji autokorelasi. Menurut Nawawi (2006:147) model regresi yang baik adalah model regresi yang berdistribusi normal.

\section{6) Uji Normalitas}

Uji normalitas berguna pada tahap awal dalam metode pemilihan analisis data. Jika data normal, maka digunakan statistik parametrik, dan jika data tidak normal, gunakan statistik nonparametrik. Tujuan uji normalitas data ini adalah untuk mengetahui apakah dalam model regresi variabel pengganggu atau residual memiliki distribusi normal. Pengujian ini diperlukan karena untuk melakukan uji t dan uji $F$ mengasumsikan bahwa nilai residual mengikuti distribusi normal. Cara yang digunakan untuk mendeteksi apakah residual mengikuti berdistribusi normal atau tidak adalah dengan analisis grafik. Jika data menyebar di sekitar garis diagonal atau grafik histogramnya menunjukkan pola distribusi normal, maka model regresi memenuhi asumsi normalitas, demikian sebelumnya. Menurut Sugiyono (2012:110), cara yang digunakan untuk mendeteksi apakah residual berdistribusi normal atau tidak adalah dengan:

1. Analisis Grafik

Salah satu cara termudah untuk melihat normalitas residual adalah dengan melihat grafik hiostogram/p-plot yang membandingkan antara data observasi dengan distribusi yang mendekati distribusi normal. Dasar pengambilan keputusannya adalah:

a) Jika data menyebar di sekitar garis diagonal dan mengikuti arah garis diagonal atau grafik histogramnya menunjukkan pola berdistribusi normal, maka model regresi memenuhi asumsi normalitas,

b) Jika data menyebar jauh dari diagonal dan tidak mengikuti arah garis diagonal atau grafik histogram tidak menunjukkan data berdistribusi normal, maka model regresi tidak memenuhi asumsi normalitas.

\section{Analisis Statistik}

"Uji statistik yang dapat digunakan untuk menguji normalitas residual adalah uji statistik KolmogrovSmirnov (K-S)" (Nawawi, 2006 : 115). Uji K-S dibuat dengan membuat hipotesis:

Ho : Data residual berdistribusi normal 
$\mathrm{Ha}$ : Data residua I tidak berdistribusi normal

Bila sig $>0,05$ dengan $\alpha=5 \%$, berarti distribusi data normal (Ho diterima), sebaliknya bila sig < 0,05 dengan $\alpha=5 \%$, berarti distribusi data tidak normal ( $\mathrm{Ha}$ diterima).

Dalam penelitian ini akan disajikan hasil uji normalitas baik melalui analisis grafik maupun analilsis statistik menggunakan bantuan program SPSS ver. 18 sebagai berikut:

\section{Gambar 4}

Grafik Kurva P-P Plot

Kompensasi Terhadap Kinerja

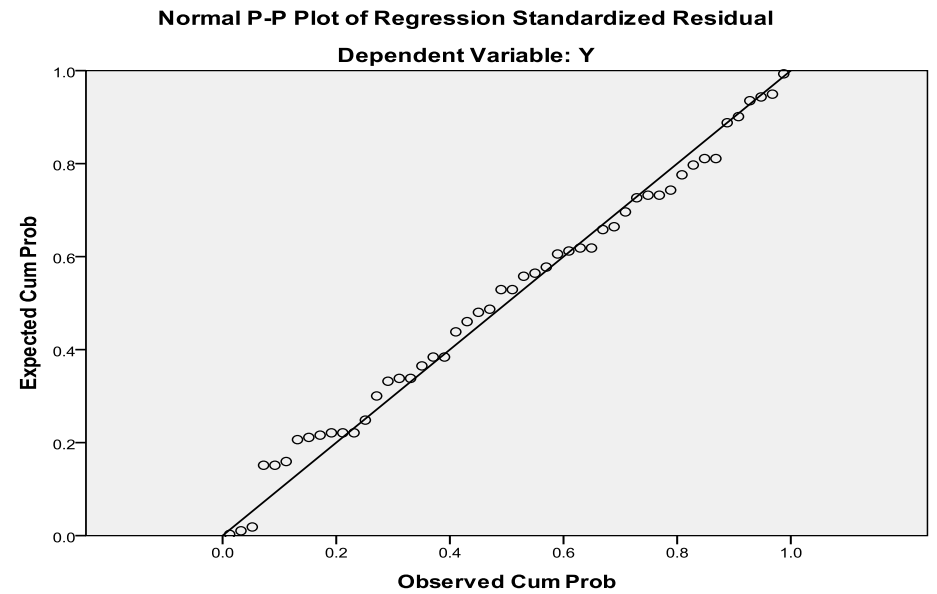

Sumber : Data primer yang diolah, 2018

Hasil kurva normal probability plot memperlihatkan bahwa titik-titik pada grafik berhimpit dan mengikuti garis diagonalnya, sehingga dapat disimpulkan model regresi berdistribusi normal.

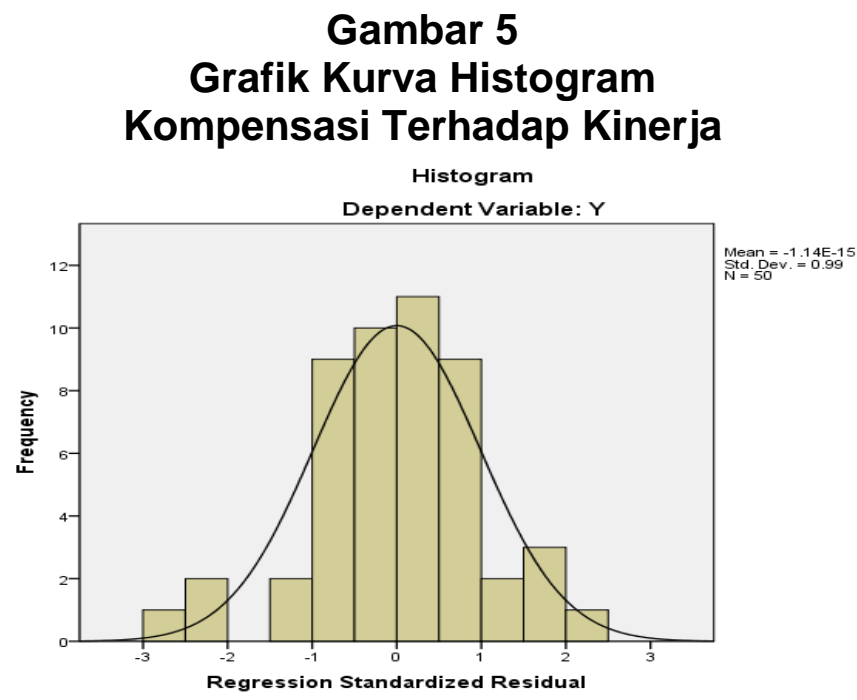

Sumber : Data primer yang diolah, 2013

Hasil kurva histogram menunjukkan bahwa bentuk kurva simetris dan tidak melenceng ke kiri maupun ke kanan sehingga berdasarkan kurva histogram, model regresi berdistribusi normal. 
Hasil analisis statistik uji normalitas dengan SPSS berdasarkan pada uji Kolmogorov-Smirnov dan
Shapiro-Wilk. Adapun Hasilnya adalah sebagai berikut :

Tabel 6

Hasil Uji Normalitas Analisis Statik

One-Sample Kolmogorov-Smirnov Test

\begin{tabular}{|c|c|c|c|}
\hline & & $\mathrm{X}$ & $\mathrm{Y}$ \\
\hline $\mathrm{N}$ & & 50 & 50 \\
\hline \multirow[t]{2}{*}{ Normal Parameters ${ }^{a, b}$} & Mean & 47.48 & 52.20 \\
\hline & Std. Deviation & 4.306 & 3.974 \\
\hline \multirow[t]{3}{*}{ Most Extreme Differences } & Absolute & .138 & .141 \\
\hline & Positive & .091 & .094 \\
\hline & Negative & -.138 & -.141 \\
\hline Kolmogorov-Smirnov Z & & .976 & 1.000 \\
\hline Asymp. Sig. (2-tailed) & & .297 & .271 \\
\hline
\end{tabular}

a. Test distribution is Normal.

b. Calculated from data.

Sumber : Data primer yang diolah, 2013

Cara mengetahui signifikan atau tidak signifikan hasil uji normalitas adalah dengan memperhatikan bilangan pada kolom signifikansi (Asymp. Sig. (2-tailed).) untuk menetapkan kenormalan, kriteria yang berlaku adalah sebagai berikut:

1. Tetapkan taraf signifikansi uji misalnya $\alpha=0,05$

2. Bandingkan $p$ dengan taraf signifikansi yang diperoleh
a) Jika signifikansi yang diperoleh $>\alpha$, maka sampel berasal dari populasi yang berdistribusi normal.
b) Jika signifikansi yang diperoleh < $\alpha$, maka sampel bukan berasal dari populasi yang berdistribusi normal.

Berdasarkan tabel di atas, diperoleh nilai signifikansi variabel $X=$ 0,297 dan $Y=0,271$, sehingga $>\alpha$. Dengan demikian sampel berasal dari populasi yang berdistribusi normal.

\section{7) Analisis Regresi Linear}

Analisis regresi digunakan untuk memprediksi seberapa jauh nilai variabel terikat $(Y)$ bila variabel bebas (X) diubah.
Sugiyono menjelaskan bahwa : "analisis regresi digunakan untuk melakukan prediksi, bagaimana perubahan nilai variabel dependen bila naik variabel independen dinaikkan atau diturunkan nilainnya."

Menurut Sugiyono (2012:270) rumus untuk analisis regresi linear adalah sebagai berikut :

$$
Y=a+b X
$$

Dimana :

$\mathrm{Y}=$ Subyek dalam variabel dependen yang diprediksikan

$\mathrm{a}=$ Harga $\mathrm{Y}$ bila $\mathrm{X}=0$ (harga konstan)

$\mathrm{b}=$ Angka arah atau koefisien regresi, yang menunjukkan angka peningkatan ataupun penurunan variabel dependen yang didasarkan pada variabel independen. Bila b (+) maka naik, dan bila (-) maka terjadi penurunan.

$X=$ Subyek pada variabel independen yang mempunyai nilai tertentu.

Teknik analisis yang digunakan dalam penelitian ini adalah teknik analisis regresi linear sederhana, dengan bantuan program SPSS ver. 18. Adapun hasilnya sebagai berikut: 
Hasil Analisi Regresi Linear Model Summary ${ }^{b}$

\begin{tabular}{|l|r|r|r|r|}
\hline Model & $\mathrm{R}$ & $\mathrm{R}$ Square & \multicolumn{1}{c|}{$\begin{array}{c}\text { Adjusted R } \\
\text { Square }\end{array}$} & $\begin{array}{c}\text { Std. Error of the } \\
\text { Estimate }\end{array}$ \\
\hline 1 & $.705^{\mathrm{a}}$ & .497 & .487 & 2.848 \\
\hline
\end{tabular}

a. Predictors: (Constant), $\mathrm{X}$

b. Dependent Variable: $Y$

ANOVA $^{b}$

\begin{tabular}{|ll|r|r|r|r|r|}
\hline Model & & Sum of Squares & df & Mean Square & F & Sig. \\
\hline 1 & Regression & 384.728 & 1 & 384.728 & 47.440 & $.000^{\mathrm{a}}$ \\
& Residual & 389.272 & 48 & 8.110 & & \\
& Total & 774.000 & 49 & & & \\
\hline
\end{tabular}

a. Predictors: (Constant), $\mathrm{X}$

b. Dependent Variable: $Y$

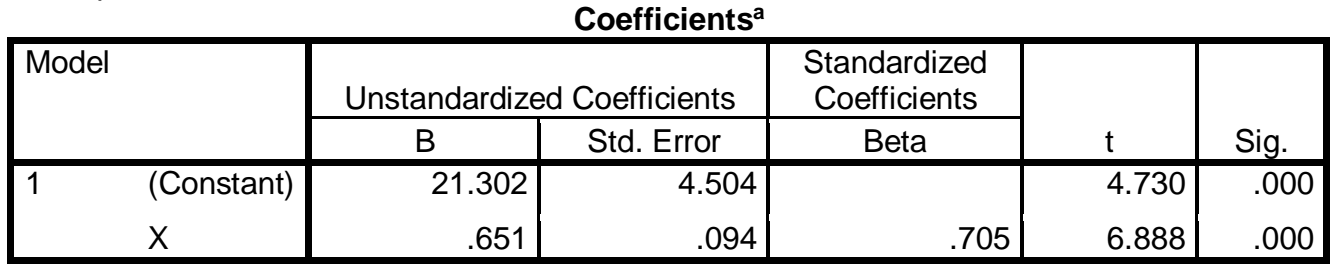

a. Dependent Variable: $Y$

Sumber : Data primer yang diolah, 2018

Berdasarkan tabel di atas maka dapat dijelaskan sebagai berikut:

1. Tabel Model Summary ${ }^{b}$ menampilkan nilai $R$ yang merupakan simbol dari nilai koefisien korelasi sebesari 0,705. Nilai ini dapat diinterprestasikan bahwa hubungan kedua variabel penelitian tergolong kuat (mendekati 1). Tabel Model Summary juga menampilkan nilai $R$ Square atau koefisien determinasi (KD) yang menunjukkan seberapa bagus model regresi yang dibentuk oleh interaksi variabel bebas dan variabel terikat. Nilai KD yang diperoleh adalah $49,7 \%$ yang dapat ditafsirkan bahwa variabel $X$ memiliki pengaruh kontribusi sebesar $49,7 \%$ terhadap variabel $\mathrm{Y}$ dan sisanya dipengaruhi oleh faktor lain diluar variabel $X$.

2. Tabel ANOVA $^{\text {b }}$ digunakan untuk menentukan taraf signifikasi atau linearitas dari regresi. Cara yang paling mudah dengan melihat nilai sig, jika sig < 0,05, maka model regresi adalah linear dan berlaku sebaliknya. Berdasarakan tabel tersebut diperoleh nilai Sig = 0,000 yang berarti < kriteria signifikan $(0,05)$, dengan demikian persamaan regresi berdasarkan data penelitian adalah signifikan dan memenuhi kriteria linearitas.

3. Tabel

Coefficients $^{a}$ menginformasikan model persamaan regresi yang diperoleh dengan koefisien konstanta dan koefisien variabel. Berdasarkan data pada tabel maka persamaan regresinya adalah:

$$
Y=21,302+0,651 X
$$

Persamaan regresi di atas dapat dijelaskan sebagai berikut:

a) Konstanta sebesar 21,302 artinya jika kompensasi $(X)$ bernilai 0 , maka kinerja karyawan (Y) nilainya adalah 21,302.

b) Koefisien regresi variabel kompensasi (X) sebesar 0,651, artinya jika kompensasi mengalami 
kenaikan $1 \%$, maka kinerja karyawan (Y) akan mengalami peningkatan sebesar 0,651. Koefisien bernilai positif artinya terjadi hubungan positif antara kompensasi dengan kinerja, semakin naik kompensasi maka semakin meningkatkan kinerja.

\section{8) Uji Hipotesis}

Pengujian hipotesis merupakan pembuktian statistik atas semua yang telah dihipotesiskan dalam penelitian bersarkan teori. Pembuktian hipotesis yang diajukan dalam penelitian ini akan dilakukan dari hasil uji parsial dengan menggunakan uji - t.

\section{9) Uji Signifikansi Pengaruh Parsial (Uji t)}

\begin{tabular}{llr}
\multicolumn{1}{c}{ Uji t } & pada & dasarnya \\
menunjukkan & seberapa & jauh \\
pengaruh satu variabel & dependen \\
secara & individual & dalam \\
menerangkan & variasi & variabel
\end{tabular}
independen (Nawawi, 2006:89). Untuk mencari nilai $t$ hitung digunakan bantuan program komputer SPSS ver. 18, dengan menggunakan significant level 0,05 ( $\alpha=5 \%)$ dengan mengacu pada hasil analisis regresi linear.

Adapun langkah-langkah pengujian sebagai berikut:

1. Menentukan Hipotesis

$\mathrm{H}_{\mathrm{o}}$ : Tidak ada pengaruh secara signifikan antara kompensasi dengan kinerja.

$\mathrm{H}_{\mathrm{a}}$ : Ada pengaruh secara signifikan antara kompensasi dengan kinerja.

2. Menentukan tingkat signifikansi

Tingkat signifikansi menggunakan $\alpha=5 \%$

3. Menentukan t hitung

Berdasarkan tabel diperoleh $t$ hitung sebesar 6,888

4. Menentukan t tabel
Tabel distribusi $\mathrm{t}$ dicari pada $\alpha=$ $5 \%$ dengan derajat kebebasan (df) $n-2$ atau $50-2=48$ ( $n$ adalah jumlah responden dan 2 adalah jumlah variabel). Dengan pengujian 2 sisi (signifikansi = 0,05 ) hasil diperoleh untuk t tabel sebesar 2,011;

5. Menentukan kriteria pengujian

a) Jika t hitung < t tabel maka Ho diterima dan Ha ditolak.

b) Jika t hitung $>$ t tabel maka Ho ditolak dan Ha diterima.

6. Membandingkan t hitung dengan $t$ tabel

Nilai $\mathrm{t}$ hitung $>\mathrm{t}$ tabel $(6,888>$ 2,011) maka Ho ditolak.

7. Kesimpulan

Oleh karena nilai t hitung $>\mathrm{t}$ tabel $(6,888>2,011)$ dan nilai signifikansinya adalah sebesar 0,000 lebih kecil daripada taraf signifikansi (a) 0,05, maka Ho ditolak, artinya bahwa ada pengaruh secara signifikan antara kompensasi dengan kinerja. Jadi dalam kasus ini dapat disimpulkan bahwa kompensasi berpengaruh terhadap kinerja pada PT Anugrah Tractor Machinery Sumatera.

\section{H. Kesimpulan dan Saran}

1. Kesimpulan

Penelitian ini bertujuan untuk mengetahui pengaruh kompensasi terhadap kinerja karyawan PT Anugrah Tractor Machinery Sumatera. Berdasarkan analisis data dan pembahasan yang telah dilakukan, maka dapat ditarik kesimpulan sebagai berikut:

1. Kompensasi berpengaruh positif dan signifikan terhadap kinerja. Hal ini ditunjukkan dengan dari hasil perhitungan diperoleh $\mathrm{R}$ Square sebesar 0,497 yang dapat diartikan bahwa besarnya pengaruh variabel bebas terhadap variabel terikat 
dalam penelitian ini sebesar $49,7 \%$ dan yang lainnya dipengaruhi oleh variabel lain diluar variabel penelitian, sehingga adanya peningkatan pemberian kompensasi akan meningkatkan kinerja karyawan.

2. Pernyataan di atas juga diperkuat oleh hasi uji-t, oleh karena nilai $t$ hitung $>$ t tabel $(6,888>2,011)$ dan nilai signifikansinya adalah sebesar 0,000 lebih kecil daripada taraf signifikansi $(\alpha)$ 0,05, maka Ho ditolak, artinya bahwa ada pengaruh secara signifikan antara kompensasi dengan kinerja. Jadi dalam kasus ini dapat disimpulkan bahwa kompensasi berpengaruh terhadap kinerja pada PT Anugrah Tractor Machinery Sumatera.

\section{Saran}

Berdasarkan hasil penelitian dan kesimpulan diatas, maka peneliti perlu memberikan saran-saran, antara lain:

1. Peneliti selanjutnya

Dapat dimanfaatkan sebagai rujukan dalam melakukan penelitian berikutnya terutama mengenai kompensasi terhadap kinerja dengan mengembangkan variabel kompensasi dipisahkan menjadi kompensasi finansial dan kompensasi non finansial, dan bisa menambahkan variabel-variabel yang lainnya.

2. Bagi Perusahaan

- Penelitian ini dapat dijadikan sebagai dasar pengambilan keputusan bagi PT Anugrah Tractor Machinery Sumatera yang sebaiknya mempertahankan dan meningkatkan kompensasi, karena variabel ini dapat meningkatkan kinerja karyawannya.

- Berdasarkan rata-rata persepsi jawaban responden, pemberian tunjuangan, insentif, dilihat skor angka rata-rata yang diberikan responden untuk indikator ini paling tinggi dibandingkan indikator lain. Ini harus dipertahankan atau lebih baik lagi untuk ditingkatkan. Disisi lain perusahaan sebaiknya lebih memperhatikan sistem pemberian gaji dan upah, karena indikator kompensasi ini mendapatkan persepsi terendah dari karyawan.

\section{DAFTAR PUSTAKA}

Arikunto, Suharsimi. 2006. Prosedur Penelitian Suatu Pendekatan Praktek. Penerbit Rineka Cipta. Jakarta

Hadari, Nawawi. 2005. Metode Penelitian Bidang Sosial, Gadjah Mada University Press, Yogyakarta

Martoyo, Susilo, 2011, Manajemen Sumber Daya Manusia, BPFE, Yogyakarta

Rahmawati, Kusdiyah, Ike. 2007. Manajemen Sumber Daya Manusia, Andi Offset. Jakarta

Samsudin, Sadili, 2009, Manajemen Sumber Daya Manusia, Pustaka Setia, Jakarta

Sugiyono. 2012, Metode Penelitian Kuantitatif, Kualitatif, dan $R \& D$, Alfabeta. Bandung. 